\title{
SiM
}

\section{Grazing Nassella}

\section{Maintaining Purple Needlegrass in a Sea of Aggressive Annuals}

\author{
By Melvin R. George, Stephanie Larson-Praplan, Morgan Doran, and Kenneth W. Tate
}

\section{On the Ground}

- Purple needlegrass responds positively to early spring grazing that reduces competition from invasive annuals.

- Rest during flowering allows for seed set and regrowth before soil moisture is depleted.

- Dry season grazing can create a harsh soil surface microclimate during germination and seedling establishment of competing annuals the following year.

- Purple needlegrass is not preferred by grazing livestock during the dry season, but high stock densities can increase its utilization.

Keywords: native grass, purple needlegrass, defoliation, clipping, tillering, regrowth.

Rangelands 35(2):17-21

doi: 10.2111/RANGELANDS-D-12-00077.1

(C) 2013 The Society for Range Management

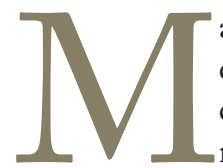

aintaining purple needlegrass populations requires informed grazing management but defoliation or grazing effects on native perennial grasses in California's annual-dominated rangelands have received little attention because they were not the dominant or key species for management. These native perennial grasses begin vegetative growth in the fall after the first rains, grow slowly during the winter, and then grow rapidly with warming spring temperatures. Vegetative growth peaks and flowering begins by April, but some vegetative growth can continue into June. ${ }^{1,2}$ Surrounding annual vegetation begins flowering by early April and reaches its peak standing crop as soil moisture is depleted, commonly in late April or May. ${ }^{1-3}$

As demand for native grass restoration in California's grazed annual rangelands increases, rangeland managers and restoration ecologists have become interested in how growth of native grasses, especially purple needlegrass (Nassella pulchra [synonym Stipa pulchra]) is affected by defoliation. A1though intense continuous grazing is one of the disturbances that contributes to the loss of native perennial grasses and their replacement by nonnative annual grasses and forbs, little is known about the growth response of these native grasses to intensity, season, frequency, and duration of defoliation. ${ }^{4}$

Our objective in this article is to compile grazing guidelines for purple needlegrass, supported by scientific literature and manager experience, and to report on a 2-year clipping study of the effect of defoliation frequency and intensity on purple needlegrass regrowth during the rapid spring growth period.

\section{Grazing Exclusion}

Responses of native grasses to grazing exclusion have been inconsistent. In one study, Pacific hairgrass (Deschampsia bolciformis) increased in response to protection from grazing but California oatgrass (Danthonia californica) decreased., In another study, California oatgrass increased with grazing removal. ${ }^{7}$ Researchers have observed that moderate or even heavy grazing stimulated vegetative growth in California oatgrass and reduced competing annuals. ${ }^{8}$

Studies have shown that purple needlegrass can increase, decrease, or remain stable when protected from grazing. ${ }^{9,10} \mathrm{~A}$ purple needlegrass stand growing on fertile soils near Berkeley, California decreased after several years of protection. ${ }^{11}$ In another study, the weight and basal area of purple needlegrass in grazed and ungrazed stands were not significantly different; however, clumps of needlegrass were smaller and more numerous in grazed stands than in ungrazed stands. ${ }^{12}$ Coastal studies in San Mateo County, just south of San Francisco, California, found that purple needlegrass decreased on grazed upper slopes but increased on grazed middle and lower slopes. ${ }^{6}$ In exclosures at the University of California Hopland Research and Extension Center (near Hopland, California) density of purple needlegrass decreased over a 21-year period and then increased to its original density after 41 years. In another exclosure, purple needlegrass remained stable over the 41 -year period. ${ }^{13,14} \mathrm{In}$ a comparison of fire and grazing effects on purple needlegrass at the Jepson Prairie south of Dixon, California, basal area increased significantly in unburned plots that were spring-grazed or summer-grazed compared to ungrazed purple needlegrass. Although not significant, needlegrass density decreased less with spring grazing than with summer grazing or no grazing. ${ }^{15}$ 
Many studies of purple needlegrass response to grazing highlight the influence of seasonal and annual variability in weather patterns on results. ${ }^{7,14,16}$

\section{Season of Grazing}

Cultivation, changes in fire frequency, drought, and possibly other disturbances contributed to the conversion of the former native perennial grassland to one dominated by nonnative annual grasses and forbs that arrived with Europeans as early as the late 1600 s. Year-round close grazing by cattle, sheep, and goats probably left little or no stubble at the end of the grazing year and was also a major contributor to the conversion. ${ }^{17,18}$ Today, purple needlegrass is the most prevalent native grass survivor of the conversion.

Some studies indicate that purple needlegrass is not very tolerant of defoliation, but other studies have found this native grass to be susceptible to competition from nonnative annual plants, and that it benefits from grazing that reduces these annual competitors. ${ }^{19-21}$ In a study from $1946-1954$, purple needlegrass was readily grazed when it was green but not grazed during the dry season due to low palatability of mature plants. ${ }^{22}$ These researchers found that they could increase utilization of mature plants by increasing stock density, but they also found that grazing over 3 successive years decreased the basal area of purple needlegrass plants. In a study of carbohydrate metabolism of purple needlegrass, early researchers concluded that moderate grazing during autumn and winter would not result in irreparable injury, but only light grazing alternating with rest periods could be tolerated during rapid spring growth that includes the flowering period. ${ }^{2}$ However, several studies have shown that purple needlegrass responds positively to early spring (April) grazing. ${ }^{7,23,24}$ The mechanism for this positive effect is not completely understood, but reduced shading and reduced seedbank of competing annuals are two explanations. Spring grazing reduces plant canopy and litter that limit light penetration to the soil surface ${ }^{25}$ where perennial grass tillers are initiated from basal buds. Reducing plant canopy and litter can increase light penetration and change the quality of light at the soil surface. Changes in the light environment have been shown to stimulate tillering in perennial grasses. ${ }^{26}$ Mowing in June has been shown to increase tillering in purple needlegrass plants when compared to unmowed plants. ${ }^{27}$ Reducing plant canopy and litter can also reduce the seedbank of competing annual grasses and forbs. ${ }^{28,29}$

Researchers have reported that spring grazing must be timed to allow perennial grass regrowth, flowering, and seed set before spring soil moisture is exhausted. ${ }^{30}$ Spring grazing must be intense enough to remove the grass inflorescences of most competing nonnative annual grasses. The result is increased livecrown cover of mature perennial grasses, reduced dead centers in bunchgrasses, improved light availability to the soil surface, ${ }^{25}$ and tiller bases that promote basal bud activation and new vegetative and reproductive tiller formation. Summer grazing when purple needlegrass is dormant or nearly dormant will remove dry residue, preventing accumulation of a thatch layer. This might require high-intensity grazing for a short period. ${ }^{30}$
Some managers have implemented spring and summer grazing to manage for native perennial grasses and to suppress nonnative annual grasses. On deep, heavy-textured soils where annual competition is great, managers of East Bay Municipal Utility District watersheds south of Orinda, California use spring grazing, followed by hard summer-fall grazing to reduce annuals ( $\mathrm{R}$. Tripp, personal communication). On shallow soils, where annual competition is not as great, spring grazing is limited to high-production years, followed by hard summer-fall grazing. According to Tripp, the hard summer-fall grazing reduces annual plant competition by reducing litter, resulting in a harsher microclimate during germination and seedling establishment.

\section{Intensity and Frequency of Grazing}

Although the benefits of grazing to reduce annual competition with native perennial grasses has been shown in several studies, ${ }^{21,31}$ the effects on intensity and frequency of defoliation on purple needlegrass and other native grasses have not been studied in traditional clipping studies. The influence of frequency and intensity of clipping has been studied on perennial grasses native to other ecosystems. In these studies, frequent clipping of individual grass plants commonly results in reduced herbage yields, indicating that intense defoliations could also reduce herbage yields. ${ }^{32-35}$ Often, defoliation intensity has little or no effect on the response to defoliation, but adequate recovery time from the last defoliation and the period of time between defoliation events significantly decreases the negative effect of defoliation. ${ }^{36}$ Rotational grazing that incorporates a rest or recovery period between grazing periods has been observed to improve vigor and abundance of purple needlegrass. ${ }^{37}$ Many studies have shown that the number of tillers can be reduced by clipping or grazing. ${ }^{38}$ However, tiller response to defoliation can be variable due to species differences, phenological status at the time of defoliation, and the frequency and intensity of defoliation. ${ }^{38-40}$

\section{Purple Needlegrass Clipping Study}

Lacking studies that report purple needlegrass response to intensity and frequency of defoliation, we conducted a 2-year clipping study at two locations in northern California. Our null hypothesis was that frequency and intensity of defoliation and their interactions do not affect regrowth or tillering of purple needlegrass.

We conducted our study at two locations during the growing season in 2010 and 2011. The Marin County site was on the Wick Ranch about $2 \mathrm{~km}$ west of Nicasio, California on a complex of the Felton (Ultic Haploxeralfs) and Soulajule (Pachic Ultic Argixerolls) soil series. The Yolo County site was on the Bobcat Ranch $10 \mathrm{~km}$ northwest of Winters, California. This site is in a small valley on a Rincon Silty Clay Loam (Mollic Haploxeralfs). The climate at both study sites is Mediterranean with an average annual rainfall of $80 \mathrm{~cm}$ to $100 \mathrm{~cm}$ at the coastal Marin County location and $40 \mathrm{~cm}$ at the inland Yolo County location. 
We measured the basal area of 40 marked purple needlegrass plants and assigned them to one of four basal area size classes of 10 plants each. The 10 plants with the smallest basal area were placed in the smallest class and the 10 plants with the largest basal area were placed in the largest class. We then randomly allocated plants in each size class to the 10 intensity $\times$ frequency treatment combinations. Study treatments included intensity of defoliation (down to 0-, 2.5-, 5-, 10-, or 20-cm height) and frequency of defoliation (weekly or monthly). Beginning in early March 2010 and 2011, we clipped individual plants to $0,2.5,5,10$, and $20 \mathrm{~cm}$ above the ground at weekly or monthly intervals until the end of the growing season in late May. We replicated each treatment four times at each study site. The clipped herbage from individual plants was dried, weighed, divided by basal area, and reported as $\mathrm{mg}$ of regrowth $/ \mathrm{cm}^{2}$ of basal area. We analyzed the data using generalized linear model analysis (GLM). Response variables were total season regrowth $\left(\mathrm{mg} / \mathrm{cm}^{2}\right)$ and number of new tillers $/ \mathrm{cm}^{2}$. GLM analysis of regrowth data was based on the normal probability distribution, whereas tiller count analysis was based on the Poisson distribution ${ }^{41}{ }^{42}$ We conducted separate analyses for each site and year. Fixed independent effects in each analysis were frequency and intensity of defoliation, and the interaction of these two terms.

Weekly clipping of purple needlegrass resulted in significantly greater tiller numbers than monthly clipping at Bobcat Ranch but not at Wick Ranch (Fig. 1). Regrowth was significantly greater ${ }^{\text {ii }}$ for monthly clipping than weekly clipping for both years at Bobcat Ranch and in 2011 at Wick Ranch (Fig. 2). There were no significant differences for tillering or regrowth for intensity of clipping at either frequency or location. We can reject the null hypotheses that frequency of clipping has no effect on regrowth or tillering. We cannot reject the null hypothesis that intensity of clipping does not influence regrowth or tillering.

Although growing season regrowth and tiller numbers were not significantly different for the clipping height treatments, the number of tillers surviving to the end of the growing season was reduced because two of the four plants clipped to the ground every week at Bobcat Ranch and all of the plants clipped to ground level at Wick Ranch died by the end of the study.

Regrowth at the Bobcat Ranch was four- to ten-fold greater than that at the Wick Ranch. The Bobcat Ranch study site was on deep alluvial soils that are often dryfarmed and could be used for irrigated crop production if water were available. The Wick Ranch is on steeper coastal mountain soils with cooler mean air and soil temperatures than the Bobcat Ranch. The Bobcat Ranch study site had been reseeded with purple needlegrass about 5 years before the study; the needlegrass on the Wick Ranch was a remnant population of unknown age.

$P=0.046$

ii $P<0.05$.

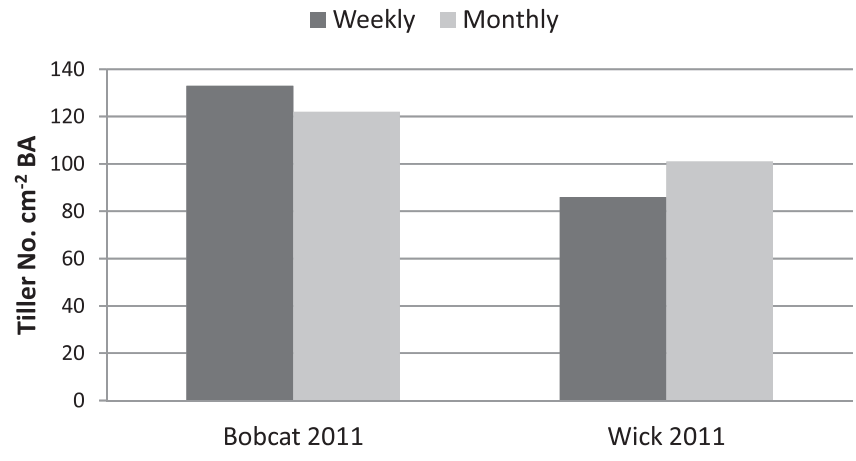

Figure 1. Growing season tiller numbers $/ \mathrm{cm}^{2}$ of basal area during 2011 for weekly and monthly clipping for 2 years at two locations.

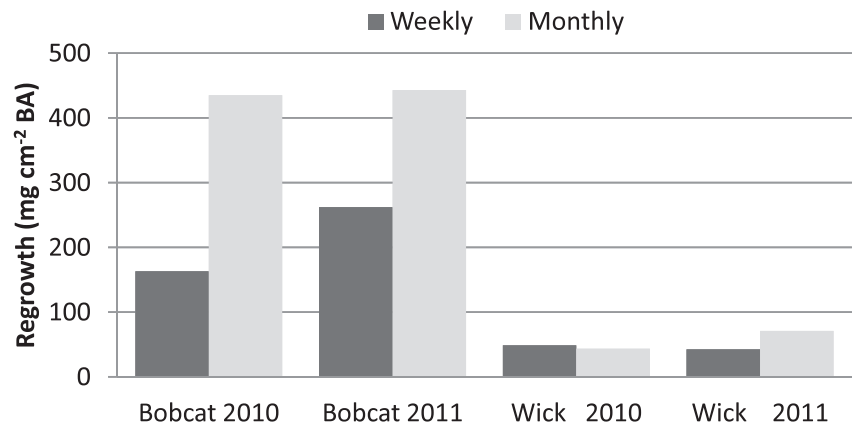

Figure 2. Growing season regrowth for weekly and monthly clipping for 2 years at two locations.

The results of our study show that frequency of grazing is an important consideration in the management of purple needlegrass. Weekly clipping closely simulates the frequency of grazing that can occur under continuous grazing, whereas the monthly clipping reflects grazing frequencies under a rotational grazing system with 4 weeks of rest between grazing periods. The results of our study demonstrate the value of rest for regrowth associated with rotational grazing systems and the potential impact of continuous grazing during the growing season on regrowth. Although rotational grazing systems on rangelands seldom result in increased forage or animal productivity, rest can benefit plant vigor and competitive ability that is important to long term survival of this native perennial grass. ${ }^{43}$

Even though the intensity of clipping had no significant effect on regrowth and tillering, the very intense treatment of clipping plants to ground level eventually resulted in plant death. This intense treatment removed all tillers and might have removed axillary buds that become tillers. Most clipping studies do not include clipping to ground level. We included this treatment to determine if survival would be reduced.

Reduced regrowth at the colder Wick Ranch site suggests that abiotic factors can influence a plant's ability to recover from close and frequent defoliation. Under colder growing conditions, regrowth is slower, so less frequent defoliation might be necessary to improve purple needlegrass's competitive ability in a "sea of annual grasses and forbs." During periods of more rapid growth, more intense and frequent defoliation might be tolerated. 


\section{Grazing Guidelines}

From the studies we discussed here, managing for purple needlegrass requires management of season of grazing, frequency of grazing, and intensity of grazing. Early spring and summer grazing and rest during flowering and seed set are important components of seasonal grazing. Providing for rest following grazing and avoiding prolonged close grazing are also important. We suggest the following guidelines for managing for purple needlegrass:

1) First, do no harm! Avoid grazing closely and continuously over many months and years.

2) Apply early spring grazing to reduce competition from invasive annuals.

a) On productive soils, use heavy spring grazing to reduce invasive species and follow with rest during flowering and hard summer-fall grazing to reduce litter and produce a harsh microclimate for germination and seedling establishment the following growing season.

b) On less-productive soils, limit heavy spring grazing to high-production years and follow with rest during flowering and hard summer-fall grazing to reduce litter and produce a harsh microclimate for germination and seedling establishment the following growing season.

3) Graze during the dry season to create a harsh soil surface microclimate during germination and seedling establishment the following year.

4) Rest for at least 4 weeks following spring grazing to allow regrowth and tillering. Rotational grazing can facilitate application of this rest treatment.

5) Rest during flowering to allow for seed set before soil moisture is depleted. Depending on the timing of spring grazing, Guideline 4 could accomplish this objective.

6) Avoid close grazing during the growing season. Minimum stubble height of $5-10 \mathrm{~cm}(2-4$ inches) will ensure regrowth and tillering. Close grazing (less than $2.5 \mathrm{~cm}$ ) throughout the growing season for two growing seasons in a row can result in plant mortality.

7) It might be logistically difficult to apply all of these guidelines in a timely manner to all pastures. If rest cannot be applied to all pastures during flowering and seed set annually, then this rest treatment should be rotated annually so that purple needlegrass has a chance to flower and set seed in each pasture every few years.

8) Rotational grazing can facilitate application of most of these practices. Rotational grazing that provides for at least 4 weeks of rest following grazing during the growing season, avoids grazing the same pasture during flowering each year, avoids grazing below a stubble height of $5 \mathrm{~cm}$ during the growing season, and removes standing litter during the dry season should maintain the vigor and competitive ability of purple needlegrass.

Although these guidelines should be generally applicable to most sites, intra- and interannual weather differences and site differences will influence tillering and regrowth. Consequently, grazing management must be an adaptive process that responds to prevailing conditions by adjusting the season, intensity and frequency of grazing to prevailing regrowth conditions. If it is a dry year or the site has a low production potential, then intensity and frequency of grazing should be reduced. Likewise, if the potential for regrowth is higher, then purple needlegrass might tolerate more frequent and intense grazing.

\section{Acknowledgments}

The authors wish to thank John Wick and Peggy Rathmann for use of the Wick Ranch needlegrass population for this project. The authors also would like to thank Audubon California for allowing the use of the seeded needlegrass population on Bobcat Ranch.

\section{References}

1. Jackson, L. E., And J. Roy. 1986. Growth patterns of Mediterranean annual and perennial grasses under simulated rainfall regimes of southern France and California. Oecologia 7:191-212.

2. Sampson, A. W., and E. C. McCarty. 1930. The carbohydrate metabolism of Stipa pulchra. Hilgardia 5:61-100.

3. George, M., J. Bartolome, N. McDougald, M. Connor, C. Vaughn and G. Markegard. 2001. Annual range forage production. Oakland, CA, USA: University of California, Division of Agriculture and Natural Resources. Publication ANR 8018. 9 p.

4. D’Antonio, C. M., S. J. Bainbridge, C. Kennedy, J. W. Bartolome, and S. Reynolds. 2006. Ecology and restoration of California grasslands with special emphasis on the influence of fire and grazing on native grassland species [A report to the David and Lucille Packard Foundation]. Santa Barbara, CA, USA: University of California. 99 p.

5. Foin, T. C., And M. M. Hektner. 1986. Secondary succession and the fate of native species in a California coastal prairie community. Madroño 33:189-206.

6. Натсh, D. A., J. W. Bartolome, J. S. Fehmi, and D. S. Hillyard. 1999. Effects of burning and grazing on coastal California grassland. Restoration Ecology 7:376-381.

7. Bartolome, J. W., J. S. Fehmi, R. D. Jackson, and B. AllenDiaz. 2004. Response of a native perennial grass stand to disturbance in California's Coast Range grassland. Restoration Ecology 12:279-289.

8. Heady, H. F., D. W. Cooper, J. W. Rible, and J. E. Hooper. 1963. Comparative forage values of California oatgrass and soft chess. Journal of Range Management 16:51-54.

9. Stromberg, M. R., and J. R. Griffin. 1996. Long-term patterns in coastal California grasslands in relation to cultivation, gophers, and grazing. Ecological Applications 6:1189-1211.

10. НАтсн, D. A., J. W. Bartolome, and D. S. Hillyard. 1991. Testing a management strategy for restoration of California's native grasslands. In: Proceedings of the Symposium on Natural Areas and Yosemite: Prospects for the Future; Denver, CO, USA. Denver, CO, USA: US National Park Service. p. 343-349.

11. Biswell, H. H. 1956. Ecology of California grasslands. Journal of Range Management 9:19-24.

12. White, K. L. 1967. Native bunchgrass (Stipa pulchra) on Hastings Reservation, California. Ecology 48:949-955. 
13. Bartolome, J. W., and B. Gemmill. 1981. The ecological status of Stipa pulchra (Poaceae) in California. Madroño 28:172-184.

14. Merenlender, A. M., K. L. Heise, J. W. Bartolome, and B. Allen-Diaz. 2001. Monitoring shows vegetation change at multiple scales. California Agriculture 55:42-46.

15. Dyer, A. R. 2003. Burning and grazing management in a California grassland: growth, mortality, and recruitment of Nassella pulchra. Restoration Ecology 11:291-296.

16. Marty, J. T., S. K. Collinge, And K. J. Rice. 2005. Responses of a remnant California native bunchgrass population to grazing, burning and climatic variation. Plant Ecology 181:101-112

17. Heady, H. F., J. W. Bartolome, M. D. Pitt, G. D. Savelle And M. C. Stroud. 1992. California prairie. In: R. T. Coupland [ED.]. Natural grasslands, introduction and western hemisphere. New York, NY, USA: Elsevier. p. 313-335.

18. D’Antonio, C. M., C. Malmstrom, S. A. Reynolds, and J. Gerlach. 2007. Ecology of invasive non-native species in California grassland. In: M. Stromberg, J. Corbin, and C. M. D'Antonio [eDs.]. California grassland: ecology and management. Berkeley, CA, USA: University of California Press. 408 p.

19. Jones, B. J., And R. M. Love. 1945. Improving California ranges. Berkeley, CA, USA: University of California Agricultural Experiment Station. Bulletin 842. 31 p.

20. Dyer, A. R., ANd K. J. Rice. 1997. Intraspecific and diffuse competition: the response of Nassella pulchra in a California grassland. Ecological Applications 7:484-492.

21. Malmstrom, C. M., C. J. Stoner, S. Brandenburg, and L.A. Newton. 2006. Virus infection and grazing exert counteracting influences on survivorship of native bunchgrass seedlings competing with invasive exotics. Journal of Ecology 94:264-275.

22. Green, L. R., And J. R. Bentley. 1957. Seeding and grazing trials of Stipa on foothill ranges. Berkeley, CA, USA: California Forest and Range Experiment Station. Forest Research Note No. 128.9 p.

23. Love, R. M. 1944. Preliminary trials on the effect of management on the establishment of perennial grasses and legumes at Davis, California. Journal of the American Society of Agronomy 36:699-703.

24. Langstroth, R. P. 1991. Fire and grazing ecology of Stipa pulchra grassland: a field study at Jepson Prairie [thesis]. Davis, CA, USA: University of California. $76 \mathrm{p}$.

25. Evans R. A., B. L. Kay, and J. A. Young. 1975. Microenvironment of a dynamic annual community in relation to range improvement. Hilgardia 43:79-102.

26. Deregibus, V. A., R. A. Sanchez, J.J. Casal, and M.J. Trlica. 1985. Tillering responses to enrichment of red light beneath the canopy in a humid natural grassland. Journal of Applied Ecology 22:199-206.

27. Ahmed, E. O. 1983. Fire ecology of Stipa pulchra on California annual grassland [dissertation]. Davis, CA, USA: University of California. 64 p.

28. Young, J. A., R. A. Evans, C. A. Raguse, and J. R. Larson. 1981. Germinable seeds and periodicity of germination in annual grasslands. Hilgardia 49:1-37.
29. RicE, K. J. 1989. Impacts of soil seedbanks on grassland community structure and population dynamics. In: M. A. Leck, V. T. Parker, and R. L. Simpson [EDs.]. Ecology of soil seed banks. San Diego, CA, USA: Academic Press. p. 211-230.

30. Menke, J. W. 1992. Grazing and fire management for native perennial grass restoration in California grasslands. Fremontia 20:22-25.

31. Hamilton, J. G., C. Holzapfel, and B. E. Mahal. 1999. Coexistence and interference between a native perennial grass and non-native annual grasses in California. Oecologia 121:518-526.

32. Holscher, C. E. 1945. The effects of clipping bluestem wheatgrass and blue grama at different heights and frequency. Ecology 26:148-156.

33. Dwyer, D. D., W. C. Elder, And G. Singh. 1963. Effects of height and frequency of clipping on pure stands of range grasses in north central Oklahoma. Stillwater, OK, USA: Oklahoma Agricultural Experiment Station. Bulletin B-614. 10 p.

34. Reed, J. L., And D. D. Dwyer. 1971. Blue grama response to nitrogen and clipping under two soil moisture levels. Journal of Range Management 24:47-51.

35. Buwai, M., And M.J. Trlica. 1977. Multiple defoliation effects on herbage yield, vigor, and total nonstructural carbohydrates of five range species. Journal of Range Management 30:164-171.

36. Ferraro, D. O., and M. Oesterheld. 2002. Effect of defoliation on grass growth: a quantitative review. Oikos 98:125-133.

37. Kephart, P. 2001. Resource management demonstration at Russian Ridge Preserve. Grasslands 11:8-11.

38. Jameson, D. A. 1963. Responses of individual plants to harvesting. Botanical Review 29:532-594.

39. Alexander, K. I., and K. Thompson. 1982. The effect of clipping on the frequency of the competitive interaction between two perennial grass species. Oecologia 53:251-254.

40. Vogel, W. G., and A. J. Bjugstad. 1968. Clipping of little bluestem, big bluestem, and Indiangrass. Journal of Range Management $21: 136-140$.

41. StataCorp. 2007. Stata statistical software. Release 10. College Station, TX, USA: StataCorp LP.

42. Rabe-Hesketh, S., and A. Skrondal. 2008. Multilevel and longitudinal modeling using stata. College Station, TX, USA: Stata Press. 562 p.

43. Briske, D. D., J. D. Derner, J. R. Brown, S. D. Fuhlendorf, W. R. Teague, K. M. Havstad, R. L. Gillen, A. J. Ash, and W. D. Willms. 2008. Rotational grazing on rangelands: reconciliation of perception and experimental evidence. Rangeland Ecology E Management 61:3-17.

Authors are Specialist Emeritus in Cooperative Extension, mrgeorge@ucdavis.edu (George), and Specialist in Cooperative Extension (Tate), Plant Sciences Dept, University of California, Davis, Davis, CA 95616, USA; Farm Advisor, University of California Cooperative Extension, Windsor, CA 95492, USA (Larson-Praplan); and Farm Advisor, University of California Cooperative Extension, Woodland, CA 95695, USA (Doran). 